\title{
RAPD marker assisted evaluation of chloroplast DNA variation in twelve hosta taxa
}

\author{
Hasan Mehraj $^{1,2, *}$, Subarna Sharma ${ }^{1,2}$, Kouhei Ohnishi $^{3}$, and Kazuhiko Shimasaki ${ }^{2}$ \\ ${ }^{1}$ The United Graduate School of Agricultural Sciences, Ehime University, Ehime 790-8556, Japan \\ ${ }^{2}$ Laboratory of Vegetable and Floricultural Science, Faculty of Agriculture and Marine Science, Kochi \\ University, B200 Monobe, Nankoku, Kochi 783-8502, Japan \\ ${ }^{3}$ Research Institute of Molecular Genetics, Kochi University, B200 Monobe, Nankoku, Kochi 783-8502, Japan
}

*Corresponding author: hmehraj02@yahoo.com

\begin{abstract}
Hostas are major ornamental plants for perennial shady nurseries. They have striking foliage with attractive flowers, and their leaves are sometimes used as vegetables in Japan and Korea. The objective of this study was to estimate the genetic identity and genetic distance of twelve hosta taxa and to build a UPGMA cluster for them using Random Amplified Polymorphic DNA (RAPD). Rhizomes of hostas were collected from Shikoku Island, Japan. Newly emerged unfurled hosta leaves were disrupted with Nuclei Lysis solution and then purified the genomic cpDNA. The cpDNA was dehydrated as a final point for extraction. We amplified the cpDNA of twelve taxa by means of 20 RAPD 10mer markers (Kit A: OPA-01 to OPA-20). The amplified DNA was run in $0.8 \%$ agarose gel using $1000 \mathrm{~kb}$ DNA ladder. Out of 20 RAPD markers, the genomic cpDNA was successfully amplified for fourteen. Fourteen markers generated a total of 102 fragments. We found maximum genetic distance (0.655) and minimum genetic identity (0.520) between $H$. sieboldiana - H. longissima taxa and between $H$. sieboldii - H. longissima. Estimated minimum genetic distance (0.071) and maximum genetic identity (0.931) were found between H. kikutii var. polyneuron - H. longipes var. caduca. The UPGMA dendrogram revealed the relationship among the 12 hostas. The results confirmed our hypothesis of large genetic variability among the taxa, which distinguishes the genotypes clearly. The RAPD 10mer markers were found useful in application to the evaluation of the genetic variability and diversity within taxa.
\end{abstract}

Keywords: Genetic distance, Genetic identity, Giboshi, Plantain lily, UPGMA.

Abbreviation: AFLP_Amplified fragment length polymorphism, cpDNA_Chloroplast DNA; ISSR_Inter simple sequence repeat; $G_{D_{-}}$Nei's genetic distance; $G_{I_{-}}$Nei's genetic identities; RAPD_Random amplified polymorphic DNA; SSR_Simple sequence repeats; TAE_Tris-Acetate-EDTA; UPGMA_Unweighted pair group method with arithmetic mean.

\section{Introduction}

Hosta is the genus of a popular ornamental perennial plant found in USA, Canada, Britain, Japan and China. It is generally used for its remarkable foliage and sometimes used as a vegetable in Japan. Genus Hosta includes approximately 70 species; so far Asia is the native region of 43 species which originated in Japan, Korea and China (Schmid, 1991). Hosta species are highly variable morphologically (Chung et al., 1991), and are differentiated by their floral character (Schmid, 1991). Meanwhile, cultivars are differentiated by leaf and overall plant characteristics (Grenfell, 1996). Maekawa (1940) first distinguished 31 Japanese and 7 Chinese and Korean species morphologically; and later, he reduced the number to 24 (Maekawa, 1969). Fujita (1976) also gave a report on the morphological characteristics of the Japanese species. Phenotypic evaluations of any living organism have limitations reflecting understanding at the gene level. The phenotypic characteristic[s] is [are] inherited genetically and expressions are controlled by environmental conditions. The classification of the Hosta genus is mainly based on morphological characteristics and therefore, systematic study is still incomplete. Estimation of genetic distance is important for a better understanding at the gene level. Genetic diversity of crop plants can be studied in inbred lines, pure lines or clones, in the form of germplasm accessions, species and populations. Diversity can occur at the genetic (variation in genes and genotypes), species (species richness) and ecosystem (species communities and their environment) levels. Molecular markers are the key tool for determining the relationship between genes (Ye et al., 2008). DNA polymorphism profiling is a useful technique for facilitating direct and reliable measurement of genetic variability and divergence. These techniques support the characterization of genotypes and the examination of tissues to distinguish physiological stages of plant; the outcome of these characterizations and examinations is autonomous to environmental conditions (Anita et al., 2004). Since the 1990s, the multi-locus marker system has been used to estimate plant genetic variation due to its ability to produce numerous amplicons and since sequence information is not required for molecular characterization (Koopman et al., 2008). DNA markers are generally used for the identification of genotypes and the determination of genetic similarity or dissimilarity. Molecular markers (RAPD, AFLP, SSR and ISSR) contribute to genetic divergence in terms of distinct morphological characteristics (Rezende et al., 2009). RAPD is used for the study of genetic relationships (Anita et al., 2004) and genetic variation (Salhi et al., 2005) because of its simplicity and low cost (Costa et al., 2011, Silva et al., 2012). 
Numerous studies have used RAPD marker to identify genetic diversity and divergence for hosta (Sauve et al., 2005; Ling et al., 1995), flowering and ornamental plants (Pinheiro et al., 2012; Rodrigues et al., 2012; Rezende et al., 2009; Ye et al., 2008). Genetic variation of Hosta species was studied by isozyme analysis (Chung, 1994). RAPD is useful for identifying variations in species with low genetic variability when other techniques fail to reveal differences among the individuals (Bowditch et al., 1994). Hundreds of hosta cultivars with variegated, golden, blue or green leaves are available in the nursery trade. These new cultivars often sell at high prices in Europe, America and Japan. All hybridization of this plant, which has been done by nonspecialists, has produced all of these cultivars. It is important to engage specialist breeders to develop new cultivars, but there is a lack of information on the molecular characterization of the hostas. The degree of gene difference between species may reflect their potentiality to develop breeding strategy. This study seeks to identify the extent of genetic differentiation or unity among hostas. It was hypothesized that RAPD markers will afford a better understanding of the variability and relationships among the studied taxa at the gene level. To test this hypothesis, our study estimated the genetic identity, genetic distance and UPGMA clustering of twelve taxa of hosta using RAPD markers.

\section{Results}

\section{Banding pattern}

A total of twenty RAPD markers were amplified for twelve hosta taxa. No band was found for six of the markers (OPA05, OPA-06, OPA-13, OPA-14, OPA-16, and OPA-17). We selected fourteen of the twenty markers, which had generated 102 fragments in total. All taxa showed polymorphic bands for OPA-01, OPA-02 and OPA-3 markers. The fingerprints of fourteen RAPD markers over twelve taxa are shown in Fig 1. The maximum number of bands was found for $H$. longissima (40) and the second highest was found for $H$. sieboldiana and $H$. sieboldii (35). The minimum number of bands was observed for H. nakaiana (14) (Fig 2).

\section{Genetic distance and identities}

Pairwise $G_{D}$ and $G_{I}$ for comparison between twelve hostas were shown in Table 1 . Maximum $G_{D}(0.655)$ and minimum $G_{I}(0.520)$ values were found for $H$. sieboldiana - $H$. longissima, also between $H$. sieboldii - $H$. longissima (Table $1)$. On the other hand, minimum $G_{D}(0.071)$ and maximum $G_{I}$ (0.931) values were found for $H$. kikutii var. polyneuron and H. longipes var. caduca (Table 1).

\section{Cluster analysis}

A dendrogram comprising twelve hosta taxa and UPGMA cluster had three clades for these taxa (Fig 3). Clade I comprised $H$. sieboldiana, $H$. alismifolia, and $H$. longissima while Clade III comprised $H$. kiyosumiensis and $H$. montana. Rest of the taxa belonged to Clade II. In the UPGMA cluster, very close average-linkage relationships were observed between $H$. kiyosumiensis and $H$. montana; between $H$. alismifolia and $H$. longissima; and between $H$. sieboldiana and the $H$. alismifolia - $H$. longissima cluster. Similarly, average linkage was found between $H$. kikutii var. caput-avis and $H$. longipes var. caduca; between $H$. tardiva and $H$. longipes var. gracillima; and between $H$. nakaiana and $H$. kikutii var. polyneuron. H. sieboldii had a very close averagelinkage to $H$. kikutii var. caput-avis and the $H$. longipes var. caduca cluster.

\section{Discussion}

In this study variation among the twelve hostas was assessed using fourteen successfully amplified RAPD markers (Fig 1). RAPD markers provided valuable genetic similarity and dissimilarity information for these hostas. The RAPD markers showed polymorphisms and large variability that distinguished the genotypes clearly. The high level of genetic dissimilarity among hostas (ranging from 0.071 to 0.655 ) shows a considerable level of genetic variation in the hostas and indicates a quite extensive genetic base. H. kikutii var. caput-avis and $H$. kikutii var. polyneuron had the same flowering characteristics and very little difference in morphological characteristics; a similar condition has been observed for $H$. longipes var. gracillima and $H$. longipes var. caduca (Fujita, 1976; Schmid, 1991). In the current study, we found very high genetic identity and low genetic distance $\left(G_{I}\right.$ : 0.833 and $G_{D}$ : 0.182) between $H$. kikutii var. caput-avis and $H$. kikutii var. polyneuron; and between $H$. longipes var. gracillima and $H$. longipes var. caduca $\left(G_{I}: 0.804\right.$ and $G_{D}$ : 0.218 ) (Table 1). These results revealed that $H$. kikutii var. caput-avis and $H$. kikutii var. polyneuron were very similar genetically, as were $H$. longipes var. gracillima and $H$. longipes var. caduca. Interestingly, genetic study using RAPD markers revealed that $H$. kikutii var. polyneuron differed 1 ittle genetically (i.e., maximum percentage of identity) from $H$. longipes var. caduca $\left(G_{D}\right.$ : 0.071 and $G_{I}$ : 0.931) (Table 1), although the two are quite different phenotypically. We found maximum genetic distance and minimum identity between $H$. sieboldiana $-H$. longissima and between $H$. sieboldii - $H$. longissima. Phenotypic variability is often confined because plant developmental stages and appearance influenced by environment do not afford an understanding of characteristics. RAPD markers generated banding patterns irrespective of plant developmental stage or growing environment. We identified different hostas from the phenotypic analysis by Fujita (1976) and Schmid (1991). However, the results of our study demonstrated the complex nature of the genotypic and phenotypic variations. Sauve et al. (2005) also found complexity in phenotypic and genotypic variations of hosta taxa. It has been found that phenotypically different genotypes may show variations in a few loci, while phenotypically similar genotypes may be completely different (Rodrigues et al., 2012). Similar to our study, genetic variation among the taxa through RAPD markers have been investigated in several plants (Arif et al., 2010; Da-Mata et al., 2009; Lin et al., 2009). RAPD primers are a useful tool for differentiation at the species level (Choo et al., 2009), which can reflect both coding and non-coding regions of the genome (Vanijajiva et al., 2005). In the current study, we found the RAPD marker assisted genetic variation and genetic relationship among taxa. The genetic variations within hosta taxa were directly related to the RAPD marker technique. The results of the RAPD marker assisted genetic variability analysis for hostas should be useful to hosta breeders in their hybridization work. 
Table 1. Pairwise Nei genetic distance matrix $\left(G_{D}\right)$ (below diagonal) and Nei genetic identity matrix $\left(G_{I}\right)$ (above diagonal) of twelve taxa of hosta from the binary data of fourteen RAPD markers.

\begin{tabular}{|c|c|c|c|c|c|c|c|c|c|c|c|c|}
\hline & $\mathrm{A}$ & B & C & $\mathrm{D}$ & $E$ & $\mathrm{~F}$ & $\mathrm{G}$ & $\mathrm{H}$ & I & $\mathrm{J}$ & $\mathrm{K}$ & $\mathrm{L}$ \\
\hline $\mathrm{A}$ & - & 0.647 & 0.608 & 0.520 & 0.539 & 0.627 & 0.657 & 0.608 & 0.676 & 0.647 & 0.657 & 0.667 \\
\hline B & 0.435 & - & 0.647 & 0.657 & 0.598 & 0.588 & 0.735 & 0.686 & 0.676 & 0.706 & 0.716 & 0.725 \\
\hline C & 0.498 & 0.435 & - & 0.520 & 0.618 & 0.667 & 0.696 & 0.686 & 0.814 & 0.784 & 0.696 & 0.627 \\
\hline D & 0.655 & 0.420 & 0.655 & - & 0.569 & 0.637 & 0.588 & 0.598 & 0.569 & 0.598 & 0.608 & 0.657 \\
\hline E & 0.618 & 0.514 & 0.482 & 0.565 & - & 0.794 & 0.765 & 0.735 & 0.706 & 0.735 & 0.725 & 0.696 \\
\hline $\mathrm{F}$ & 0.466 & 0.531 & 0.405 & 0.451 & 0.231 & - & 0.775 & 0.725 & 0.794 & 0.804 & 0.775 & 0.725 \\
\hline G & 0.420 & 0.307 & 0.362 & 0.531 & 0.268 & 0.256 & - & 0.892 & 0.843 & 0.833 & 0.824 & 0.833 \\
\hline $\mathrm{H}$ & 0.498 & 0.376 & 0.376 & 0.514 & 0.307 & 0.321 & 0.114 & - & 0.833 & 0.843 & 0.814 & 0.784 \\
\hline I & 0.391 & 0.391 & 0.206 & 0.565 & 0.348 & 0.231 & 0.171 & 0.182 & - & 0.931 & 0.843 & 0.775 \\
\hline $\mathrm{J}$ & 0.435 & 0.348 & 0.243 & 0.514 & 0.307 & 0.218 & 0.182 & 0.171 & 0.071 & - & 0.853 & 0.745 \\
\hline K & 0.420 & 0.335 & 0.362 & 0.498 & 0.321 & 0.256 & 0.194 & 0.206 & 0.171 & 0.159 & - & 0.853 \\
\hline $\mathrm{L}$ & 0.405 & 0.321 & 0.466 & 0.420 & 0.362 & 0.321 & 0.182 & 0.243 & 0.256 & 0.294 & 0.159 & - \\
\hline
\end{tabular}
longipes var. caduca, $\mathrm{K}=H$. kiyosumiensis, and $\mathrm{L}=H$. montana.

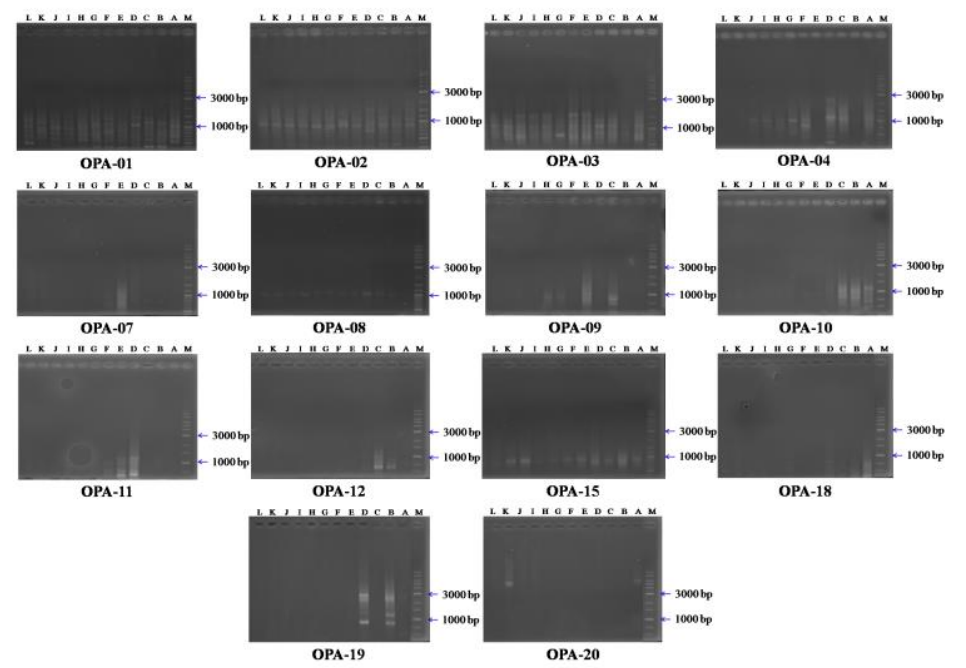

Fig 1. The fingerprints for fourteen RAPD markers for studied taxa of hosta . Here, $\mathrm{A}=H$. sieboldiana, $\mathrm{B}=$ H. alismifolia $\mathrm{C}=H$. sieboldii, $\mathrm{D}=H$. longissima, $\mathrm{E}=H$. tardiva, $\mathrm{F}=H$. longipes var. gracillima, $\mathrm{G}=H$. nakaiana, $\mathrm{H}=H$. kikutii var. caput-avis, $\mathrm{I}=H$. kikutii var. polyneuron, $\mathrm{J}=H$. longipes var. caduca, $\mathrm{K}=H$. kiyosumiensis, $\mathrm{L}=H$. montana and $\mathrm{M}=$ DNA ladder. 
Table 2. A list of the twenty RAPD primers used for the amplification of twelve Hosta taxa in the present study.

\begin{tabular}{llll}
\hline Primer Name & Sequences $\left(5^{\prime}-3^{\prime}\right)$ & Primer Name & Sequences $\left(5^{\prime}-3^{\prime}\right)$ \\
\hline OPA-01 & CAGGCCCTTC & OPA-11 & CAATCGCCGT \\
OPA-02 & TGCCGAGCTG & OPA-12 & TCGGCGATAG \\
OPA-03 & AGTCAGCCAC & OPA-13 & CAGCACCCAC \\
OPA-04 & AATCGGGCTG & OPA-14 & TCTGTGCTGG \\
OPA-05 & AGGGGTCTTG & OPA-15 & TTCCGAACCC \\
OPA-06 & GGTCCCTGAC & OPA-16 & AGCCAGCGAA \\
OPA-07 & GAAACGGGTG & OPA-17 & GACCGCTTGT \\
OPA-08 & GTGACGTAGG & OPA-18 & AGGTGACCGT \\
OPA-09 & GGGTAACGCC & OPA-19 & CAAACGTCGG \\
OPA-10 & GTGATCGCAG & OPA-20 & GTTGCGATCC \\
\hline
\end{tabular}

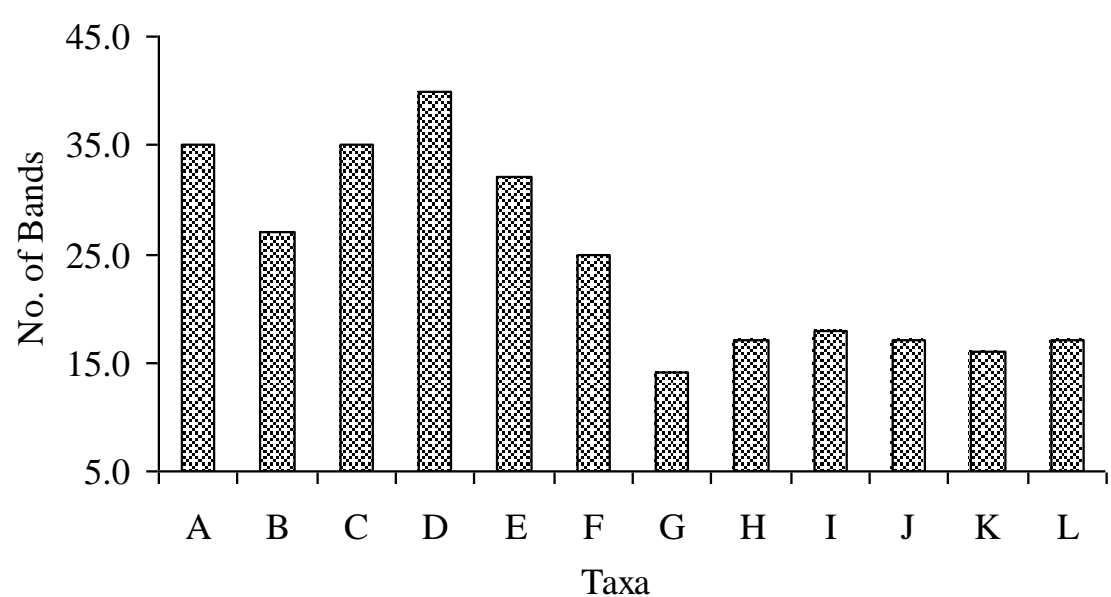

Fig 2. Total number of bands from binary data for twelve hosta taxa.

Here, $\mathrm{A}=H$. sieboldiana, $\mathrm{B}=H$. alismifolia, $\mathrm{C}=H$. sieboldii, $\mathrm{D}=H$. longissima, $\mathrm{E}=H$. tardiva, $\mathrm{F}=H$. longipes var. gracillima, $\mathrm{G}=H$. nakaiana, $\mathrm{H}=H$. kikutii var. caput-avis, $\mathrm{I}=H$. kikutii var. polyneuron, $\mathrm{J}=H$. longipes var. caduca, $\mathrm{K}=H$. kiyosumiensis, and $L=H$. montana 


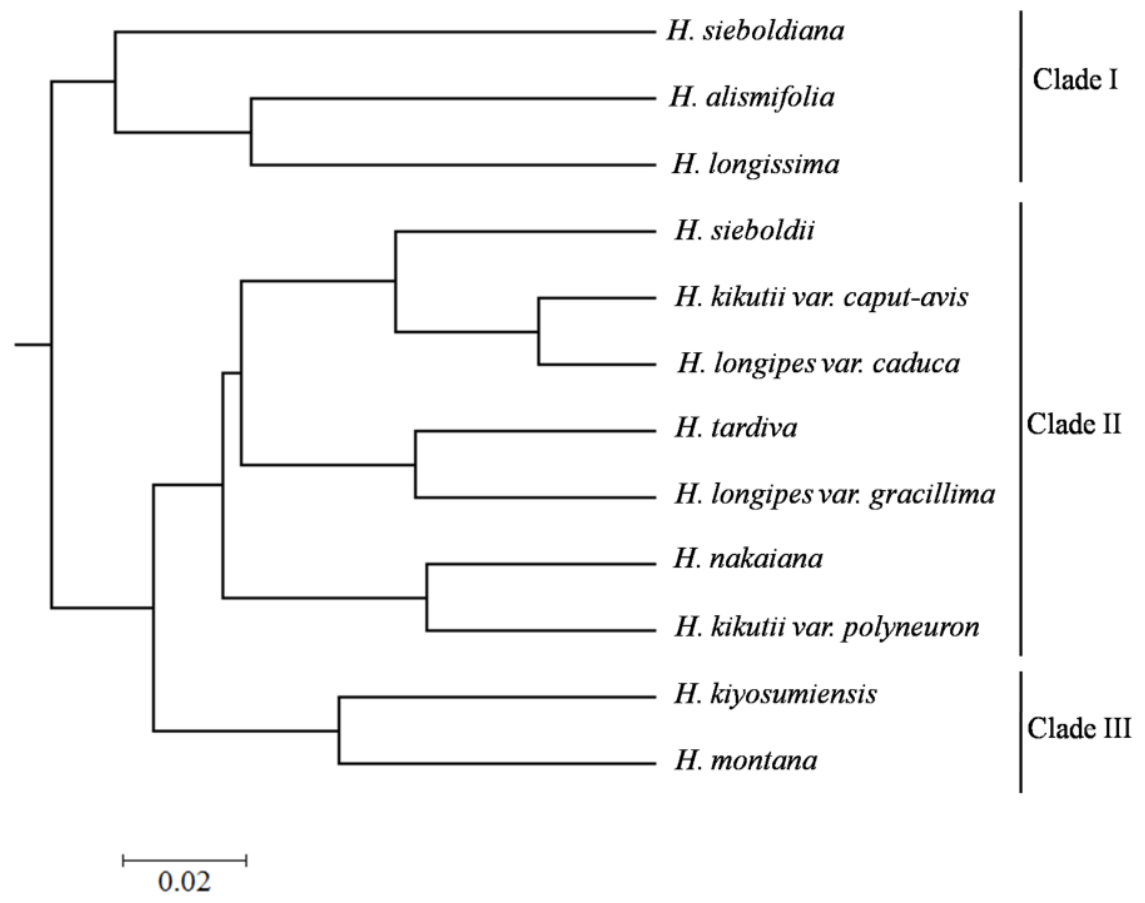

Fig 3. UPGMA cluster for twelve hosta taxa based on fourteen successfully generated fragments of RAPD markers The dendrogram was constructed by successive (agglomerative) clustering using an average-linkage method.

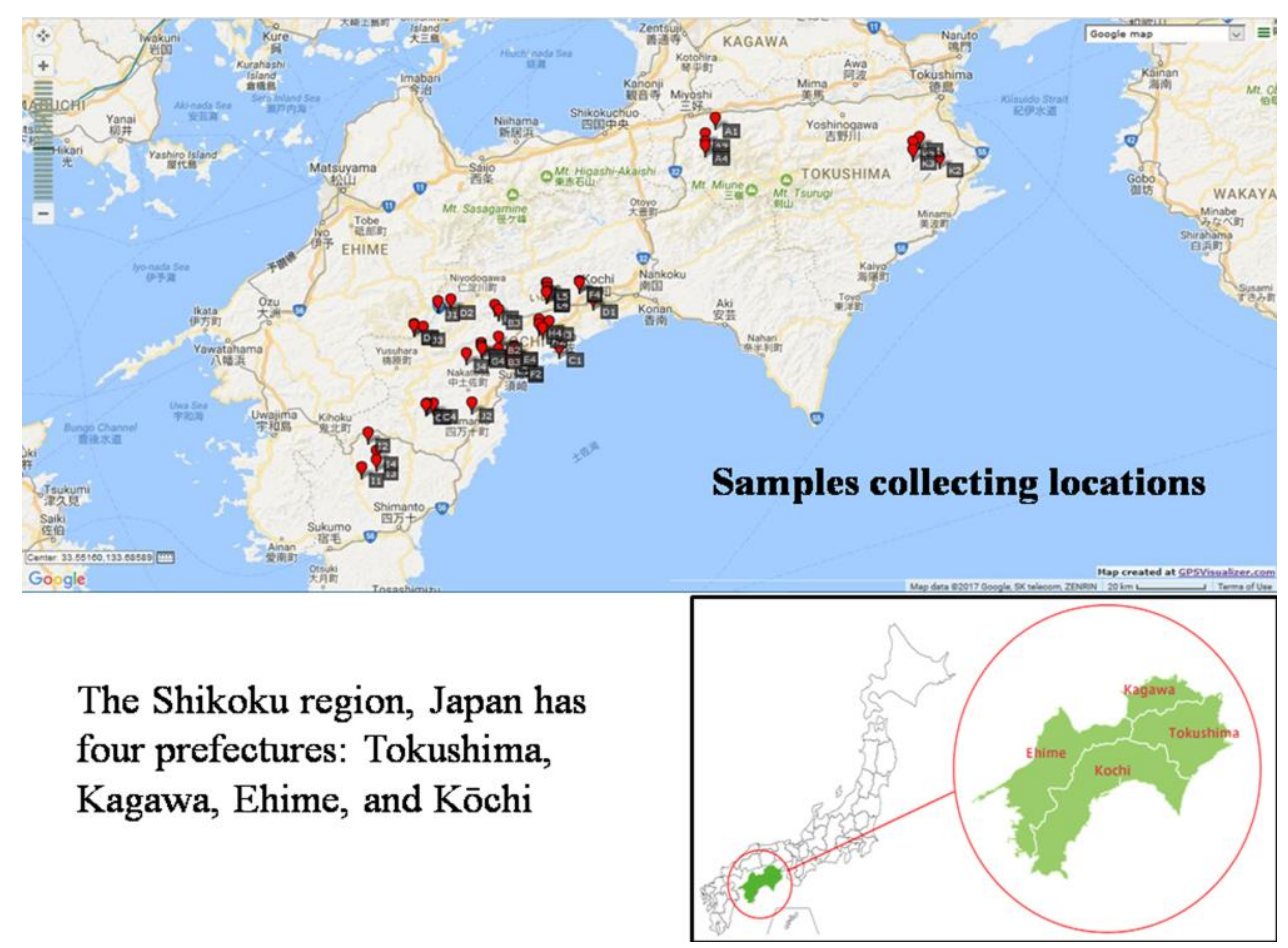

Fig. 4. Sample collection localities of hostas, collected from Shikoku Island, Japan. GPS data were plotted in GPS Visualizer for visualization of the sample collection site. Source: Map of Shikoku Region, Japan was Japanese Encyclopedia. Here, A1-A4 $=H$. sieboldiana, B1-B4 $=H$. alismifolia, $\mathrm{C} 1-\mathrm{C} 4=H$. sieboldii, D1-D4 $=H$. longissima, $\mathrm{E} 1-\mathrm{E} 4=H$. tardiva, $\mathrm{F} 1-\mathrm{F} 4=H$. longipes var. gracillima, $\mathrm{G} 1-\mathrm{G} 4=H$. nakaiana, $\mathrm{H} 1-\mathrm{H} 4=H$. kikutii var. caput-avis, I1-I4 = H. kikutii var. polyneuron, $\mathrm{J} 1-\mathrm{J} 4=H$. longipes var. caduca, $\mathrm{K} 1-\mathrm{K} 4=H$. kiyosumiensis, L1-L5 = H. montana 


\section{Materials and methods}

\section{Plant materials}

First, rhizomes of $H$. sieboldiana, $H$. alismifolia, $H$. sieboldii, $H$. longissima, $H$. tardiva, $H$. longipes var. gracillima, $H$. nakaiana, $H$. kikutii var. caput-avis, $H$. kikutii var. polyneuron, $H$. longipes var. caduca, $H$. kiyosumiensis, and H. montana were collected from Shikoku area, Japan (Fig. 4) and planted in pots to emerge new leaves. Four to five plants of each taxon were grown. Newly emerged unfurled hosta leaves were collected [4 samples for each taxon for repetition (except $H$. montana; 5 samples)] for cpDNA extraction.

\section{Extraction of cpDNA}

40-60 mg of newly emerged hosta leaves were washed in $70 \%$ ethanol. The leaves were kept in a microcentrifuge tube with a Zirconia bead. Nuclei Lysis solution $(600 \mu \mathrm{l})$ was added to the microcentrifuge tube and disrupted with a Micro Smash MS-100 bead beater (at $3500 \mathrm{rpm}$ for 3 minutes) (Tomy Seiko, Tokyo, Japan). We followed the manufacture's instructions (Wizard $^{\circledR}$ Genomic DNA Purification Kit, Promega, Wisconsin, USA) for the purification of genomic cpDNA. We dehydrated the purified genomic cpDNA with DNA Rehydration solution $(100 \mu \mathrm{l})$ as a final stage of extraction. The resultant dehydrated cpDNA was preserved at $4^{0} \mathrm{C}$, was ready for use in the amplification.

\section{Amplification of cpDNA}

We used RAPD 10mer Kit A (OPA-01 to OPA-20) (eurofins, Tokyo, Japan). We amplified the extracted cpDNA using twenty RAPD primers (Table 2 ).

\section{Components and conditions for RAPD-PCR}

We used $13 \mu \mathrm{l}$ of distilled water; $2 \mu \mathrm{l}$ each of DNA, primer and $2 \mu \mathrm{Taq}$ polymerase reaction buffer; $1 \mu \mathrm{dNTP}$; and 0.2 $\mu \mathrm{T}$ Taq DNA polymerase for RAPD-PCR. PCR conditions were as follows: (i) $94^{\circ} \mathrm{C}$ for $10 \mathrm{~min}$; (ii) $94^{\circ} \mathrm{C}$ for $1 \mathrm{~min}$; (iii) $36^{\circ} \mathrm{C}$ for $1 \mathrm{~min}$; (iv) $72^{\circ} \mathrm{C}$ for $2 \mathrm{~min}$; (v) 45 cycles of steps ii to iv; (vi) $72^{\circ} \mathrm{C}$ for $10 \mathrm{~min}$; (viii) hold at $4^{\circ} \mathrm{C}$.

\section{Gel electrophoresis}

$5 \mu 1$ amplified DNA solution $(4 \mu 1$ Amplified DNA $+1 \mu 1$ loading dye) was run into $0.8 \%$ agarose gel for 45 minutes at 75 volt and $1 \times$ TAE buffer was used to dip gel in the electrophoresis chamber. We used $1000 \mathrm{~kb}$ DNA ladder for gel electrophoresis. We repeated the process (from amplification to gel electrophoresis) at least 2 times to avoid the error in the separation of different sized molecules.

\section{Data analysis}

PyElph was used for gel image analysis (Pavel and Vasile, 2012) to obtain binary data for the presence (1) or absence (0) of band. The total number of bands, pairwise Nei genetic distance and identity matrix (Nei, 1972) for twelve taxa were calculated using GenAlEx 6.5 (Peakall and Smouse, 2012). We built the UPGMA dendrogram by implementing Neighbor from the PHYLIP-3.695 package (Felsenstein, 2005). The output file was subjected to TreeView (Page, 1996) to explore the dendrogram.

\section{Conclusion}

RAPD provided indiscriminately observed genetic variations of the entire hosta genome. Floral and leaf characteristics of ornamental and leafy vegetables, respectively, are characteristics essential to commercial value. Though sometimes the floral and leaf characters of hostas were highly similar, genetically they were not. Phenotypically dissimilar hosta genotypes can vary in a few loci but phenotypically alike genotypes can differ completely. We expect that the RAPD assisted genetic variability analysis and the association among the studied hosta taxa that will be of considerable practical value to hosta breeders.

\section{Acknowledgement}

The authors are grateful to the Research Institute of Molecular Genetics, Kochi University, Japan for access to instrumental facilities for the conduct of the research. We are highly indebted to The United Graduate School of Agricultural Science of Ehime University, Japan; and to the Japanese Ministry of Education, Culture, Sports, Science and Technology to support the study. We are also most thankful to the lab mates who helped us with the collection of the samples.

\section{Funding}

We had no specific grant for the fund from any public, commercial or other non profitable funding agencies for this research.

\section{Conflict of interest}

We would hereby like to declare that there is no conflict of interests that could possibly arise.

\section{Authors Contribution}

Hasan Mehraj conceived, designed, and performed the experiment, analyzed the data and wrote this manuscript. Kazuhiko Shimasaki contributed the plant materials and the chemicals required. Kouhei Ohnishi demonstrated the whole experimental process. Kazuhiko Shimasaki and Kouhei Ohnishi were responsible for supervising the experiment. Subarna Sharma assisted in the performance of the entire experimental process.

\section{References}

Anita K, Małgorzata K, Edward Ż (2004) Comparison of suitability of RAPD and ISSR techniques for determination of strawberry (Fragaria $\times$ ananassa Duch.) relationship. Plant Cell Tiss Org Cul. 79: 189-193.

Arif IA, Bakir MA, Khan HA, Al Farhan AH, Al Homaidan AA, Bahkali AH, Al Sadoon M, Shobrak M (2010) Application of RAPD for molecular characterization of plant species of medicinal value from an arid environment. Genet Mol Res. 9: 2191-2198.

Bowditch BM, Albright DG, Williams JGK, Braun MJ (1994) Use of randomly amplified polymorphic DNA markers in comparative genome studies. Methods Enzymol. 224: 294-309.

Choo BK, Moon BC, Ji Y, Kim BB, Choi G, Yoon T, Kim HK (2009) Development of SCAR markers for the discrimination of three species of medicinal plants, Angelica decursiva (Peucedanum decursivum), 
Peucedanum praeruptorum and Anthricus sylvestris, based on the internal transcribed spacer (ITS) sequence and random amplified polymorphic DNA (RAPD). Biol Pharm Bull. 32: 24-30.

Chung MGJ (1994) Genetic variation and population structure in Korean endemic species: III. Hosta minor (Liliaceae). J Plant Res. 107(4): 377-383.

Chung MG, Jones SB, Hamrick JL, Chung HG (1991) Morphometric and isozymes analysis of the genus Hosta (Liliaceae) in Korea. Plant Species Biol. 6: 5569.

Costa TS, Silva AVC, Lédo AS, Santos ARF, Silva JFJr (2011) Diversidade genética de acessos do banco de germoplasma de mangaba em Sergipe. Pesquisa Agropecuária Brasileira. 46: 499-508.

Da-Mata TL, Segeren MI, Fonseca AS, Colombo CA (2009) Genetic divergence among gerbera accessions evaluated by RAPD. Sci Hort. 121: 92-96.

Felsenstein J (2005) PHYLIP (Phylogeny Inference Package) version 3.6. Distributed by the author. Department of Genome Sciences, University of Washington, Seattle.

Fujita N (1976) The genus Hosta (Liliaceae) in Japan. Acta Phytotax Geobot. 27: 66-96 (in Japanese). Website link

Grenfell D (1996) The gardener's guide to growing hosta. Timber Press, Portland.

Koopman WJM, Wissemann V, Cock KD, Huylenbroeck JV, Riek JD, Sabatino GJH, Visser D, Vosman B, Ritz CM, Maes B, Werlemark G, Nybom H, Debener T, Linde M, Smulders MJM (2008) AFLP markers as a tool to reconstruct complex relationships: A case study in Rosa (Rosaceae). Am J Bot. 95: 353 - 366.

Lin KH, Lai YC, Li HC, Lo SF, Chen LFO, Lo HF (2009) Genetic variation and its relationship to root weight in the sweet potato as revealed by RAPD analysis. Sci Hort. 120: $2-7$.

Ling JT, Gawel N, Sauve RJ (1995) RAPD analysis of hosta species and cultivars. HortSci. 30(4): 811.

Maekawa F (1940) The genus Hosta. Journal of the Faculty of Science. Imperial University Tokyo, Section 3. Botany 5: $317 \pm 425$. [Reprinted in: The American Hosta Society Bulletin (1972) 4, $12 \pm 64$ and (1973) 5, $12 \pm 59$ ]

Maekawa F (1969) Hosta Trattinnick, Vol. 3. In The encyclopedia of Horticulture. Tokyo: Seibundoshinkosha, pp. $1104 \pm 1109$.

Nei M (1972) Genetic distance between populations. Am Nat. 106: 283-292.

Page RDM (1996) Tree view: An application to display phylogenetic trees on personal computers. Bioinformatics. 12: 357-358.

Pavel AB, Vasile CI (2012) PyElph - a software tool for gel images analysis and phylogenetics. BMC Bioinformatics. 13: 9. http://dx.doi.org/10.1186/1471-2105-13-9

Peakall R, Smouse PE (2012) GenAlEx 6.5: genetic analysis in excel - population genetic software for teaching and research-an update. Bioinformatics. 28: 2537-2539.

Pinheiro LR, Rabbani ARC, da Silva AVC, da Silva LA, Pereira KLG, Diniz LEC (2012) Genetic diversity and population structure in the Brazilian Cattleya labiata (Orchidaceae) using RAPD and ISSR markers. Plant Syst Evol. 298: 1815-1825. Rezende RKS, Paiva LV, Paiva R, Chalfun JA, Torga PP, Masetto TE (2009) Genetic divergence among cultivars of gerbera using RAPD markers. Cienc Rural. 39: 2435-2440.
Rodrigues MGF, Mazzini RB, Pivetta KFL, Alves MDC, Desidério JA (2012) Characterization of the genetic variability among Caesalpinia pulcherrima (L.) Sw. (Fabaceae) plants using RAPD molecular markers. Acta Sci Agron. 34: 259-263.

Salhi HA, Chatti K, Mars M, Marrakchi M, Trifi M (2005) Comparative analysis of genetic diversity in two Tunisian collections of fig cultivars based on random amplified polymorphic DNA and inter simple sequence repeats fingerprints. Genet Resour Crop Evol. 52: 563-573.

Sauve RJ, Zhou S, Yu Y, Schmid WG (2005) Randomly amplified polymorphic DNA analysis in the genus Hosta. HortSci. 40: 1243-1245. CrossRef

Schmid WG (1991) The genus Hosta - Giboshi Zoku (ギボウ シ属). London and Portland: Batsford/Timber Press.

Silva AVC, Santos ARF, Lédo AS, Feitosa RB, Almeida CS (2012) Moringa genetic diversity from germplasm bank using RAPD markers. Trop Subtrop Agroeco. 15: 31-39. http://www.revista.ccba.uady.mx/ojs/index.php/TSA/article /view/1266

Vanijajiva O, Sirirugsa P, Suvachittanont W (2005) Confirmation of relationships among Boesenbergia (Zingiberaceae) and related genera by RAPD. Biochem Syst Ecol. 33: 159-170.

Ye YM, Zhang JW, Ning GG, Bao MZ (2008) A comparative analysis of the genetic diversity between inbred lines of Zinnia elegans using morphological traits and RAPD and ISSR markers. Sci Hortic.118:1-7. 